\title{
Photoelectrochemical Solar Cells Prepared From Nanoscale Zerovalent Iron Used for Aqueous $\mathrm{Cd}^{2+}$ Removal
}

Keyla T. Soto Hidalgo ${ }^{\mathrm{a}, \mathrm{b}, \ddagger}$, Edwin O. Ortiz-Quiles ${ }^{\mathrm{c}, \star}$, Luis E.Betancourt ${ }^{\mathrm{c}}$, Eduardo Larios ${ }^{\mathrm{d}, \mathrm{e}}$, Miguel José-Yacaman ${ }^{\text {, }}$, and Carlos R. Cabrera, ${ }^{c}$,

a. University of the Puerto Rico at Río Piedras, San Juan, Puerto Rico 00931.

b. Department of Environmental Sciences, University of Puerto Rico at Rio Piedras, San Juan, Puerto Rico 00931.

c. Department of Chemistry, University of Puerto Rico at Río Piedras, San Juan, Puerto Rico 00931.

d. Physics and Astronomy Department, University of Texas at San Antonio, San Antonio, Texas 78249, USA.

e. Departamento de Ingeniería Química, Universidad de Sonora, 83000 Hermosillo, Sonora, México.

\section{Table of Figures}

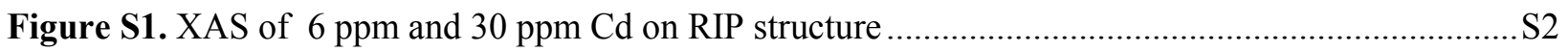

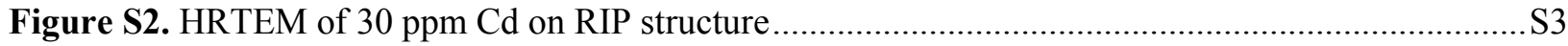




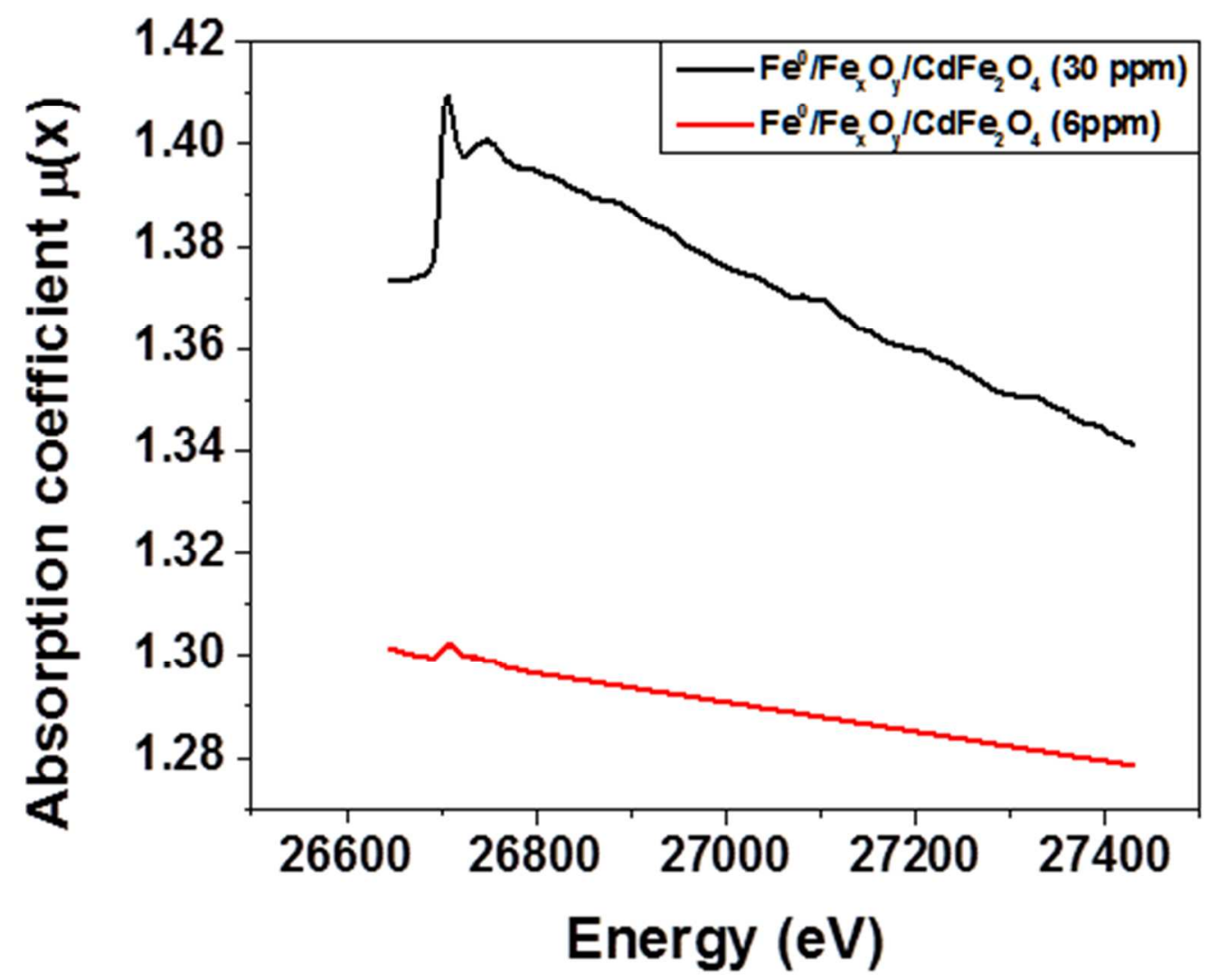

Figure S1. XAS spectra of $6 \mathrm{ppm}$ and $30 \mathrm{ppm} \mathrm{Fe} / \mathrm{Fe}_{\mathrm{x}} \mathrm{O}_{\mathrm{y}} / \mathrm{CdFe}_{2} \mathrm{O}_{4}$ structure.

It can be observed that the absorption of $6 \mathrm{ppm} \mathrm{Cd}$ is much lower than the absorption of the $30 \mathrm{ppm} \mathrm{Cd}^{2+}$ sample. The presence of $\mathrm{Cd}^{2+}$ was confirmed on both samples but the electronic structure of the $6 \mathrm{ppm} \mathrm{Cd}$ is not clearly defined for the Cd K-Edge due to the lower metal loading. Since X-ray absorption spectroscopy is an element specific technique we were able to corroborate the presence of $\mathrm{Cd}$ and their remarkable differences in terms of uptake. 

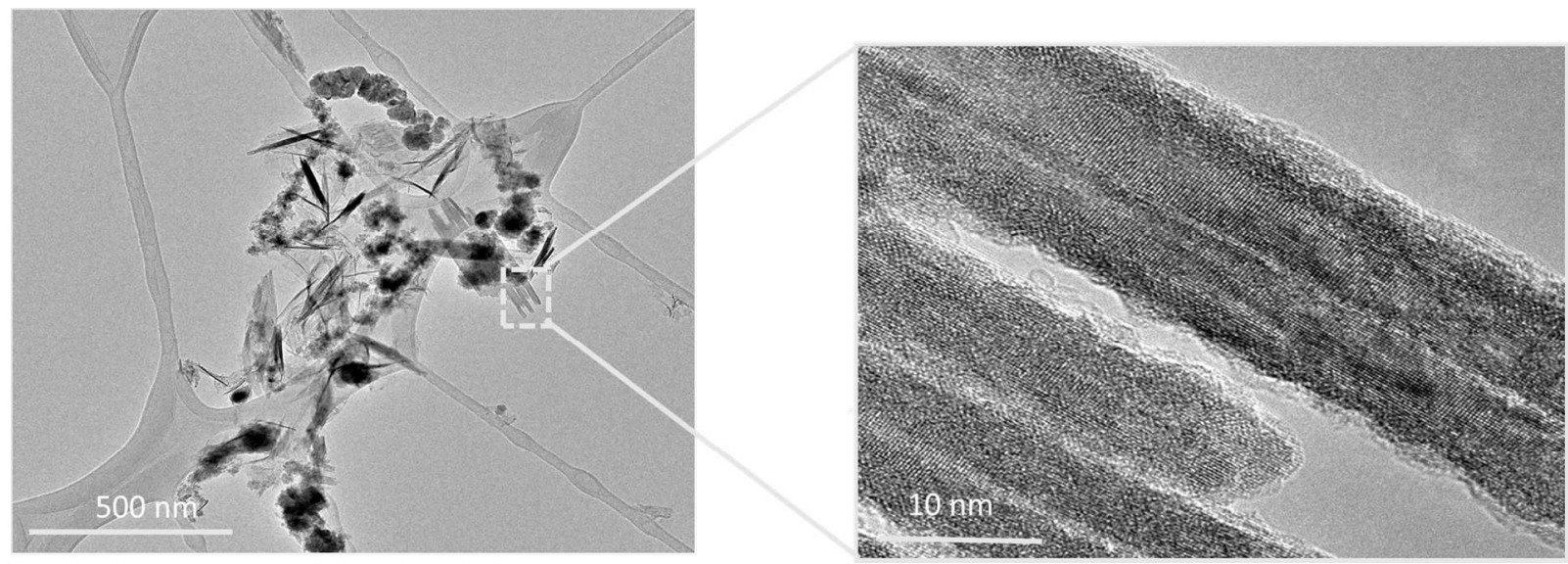

Figure S2. HR-TEM of $30 \mathrm{ppm} \mathrm{Fe}^{0} / \mathrm{Fe}_{\mathrm{x}} \mathrm{O}_{\mathrm{y}} / \mathrm{CdFe}_{2} \mathrm{O}_{4}$ structure.

A structural change can be easily observed after $\mathrm{Cd}^{2+}$ uptake in the nZVI. The formation of iron nanofibers was confirmed on both $6 \mathrm{ppm}$ and $30 \mathrm{ppm}$ Cd-RIP structures. 